Pre-print of: Eijo-Río, Elena, et al. "Municipal sewer networks as sources of nitrous oxide, methane and hydrogen sulphide emissions: A review and case studies" in Journal of Environmental Chemical Engineering Vol 3, Issue 3 (September 2015), p. 2084-2094. Elsevier. The final version is available at DOI 10.1016/j.jece.2015.07.006

\title{
Municipal sewer networks as sources of nitrous oxide, methane and hydrogen sulphide emissions: a review and case studies of Atlantic and Mediterranean-climate Spanish cities.
}

\author{
Elena Eijo-Río ${ }^{\mathrm{a}, \mathrm{bl}}$, Anna Petit-Boix ${ }^{\mathrm{a} 1}$, Gara Villalba ${ }^{\mathrm{a}, \mathrm{b} *}$, María Eugenia Suárez-Ojeda ${ }^{\mathrm{c}, *}$, Desirée \\ Marin $^{\mathrm{d}}$, Maria José Amores ${ }^{\mathrm{d}}$, Xavier Aldea ${ }^{\mathrm{d}}$, Joan Rieradevalla ${ }^{\mathrm{a}, \mathrm{b}}$, Xavier Gabarrella,b

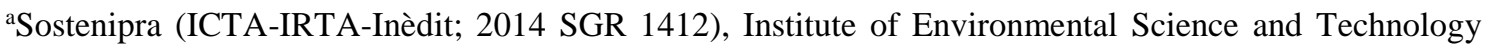 \\ (ICTA), UniversitatAutònoma de Barcelona (UAB), Edifici ICTA-ICP, Carrer de les Columnes, 08193 \\ Bellaterra, Barcelona, Spain.
}

bepartment of Chemical Engineering, Xarxa de Referència en Biotecnologia (XRB), School of Engineering, Universitat Autònoma de Barcelona, 08193 Bellaterra, Barcelona, Spain

'GENOCOV, Department of Chemical Engineering, School of Engineering, Universitat Autònoma de Barcelona, 08193 Bellaterra, Barcelona, Spain.

${ }^{\mathrm{d} C e t a q u a,}$ Water Technology Centre, 08940 Cornellà de Llobregat, Barcelona, Spain

* Corresponding authors: Dr. M.E. Suárez-Ojeda, mariaeugenia.suarez@uab.cat; Dr. Gara Villalba, gara.villalba@uab.cat

${ }^{1}$ Elena Eijo-Río and Anna Petit-Boix contributed equally to this paper and share first authorship

\begin{abstract}
The formation of Greenhouse Gases (GHG) in wastewater infrastructures has been mainly assessed in Wastewater Treatment Plants (WWTP). However, sewers are longitudinal reactors where gases such as methane $\left(\mathrm{CH}_{4}\right)$, nitrous oxide $\left(\mathrm{N}_{2} \mathrm{O}\right)$ and hydrogen sulphide $\left(\mathrm{H}_{2} \mathrm{~S}\right)$ can also be produced. This article presents a critical review of studies that quantify the generation of these gases in sewers and identifies the existing research gaps. Differences in the sampling methods and site selection, as well as a very limited number of studies, result in incoherent comparison amongst emissions from sewers. In order to address some of these gaps, sampling campaigns were conducted in two Spanish cities in winter and summer. Results showed that wet wells, where turbulence enables the gas release from the liquid phase, were the most important sources of gases with concentrations up to $321 \mu \mathrm{g} \mathrm{CH}_{4} \mathrm{~L}_{\text {air }}{ }^{-1}$ and $6.8 \mu \mathrm{g} \mathrm{N}_{2} \mathrm{O} \mathrm{Lair}^{-1}$. Regarding emission factors, in the case of Calafell, the estimated annual emissions were up to 7,447 $\mathrm{kg} \mathrm{CH}_{4}$ and $134 \mathrm{~kg} \mathrm{H}_{2} \mathrm{~S}$ in summer and $1,886 \mathrm{~kg} \mathrm{CH}_{4}$ and $255 \mathrm{~kg} \mathrm{H}_{2} \mathrm{~S}$ in winter. Regarding Betanzos, these values were $12,087 \mathrm{~kg} \mathrm{CH}_{4}$ and $265 \mathrm{~kg} \mathrm{~N}_{2} \mathrm{O}$ in summer and 4,771 $\mathrm{kg} \mathrm{CH}_{4}$ in winter. The summer campaign resulted in greater gas concentration than in the winter season for both cities, suggesting that temperature is a highly influential parameter. We conclude that gas emissions from sewers are significant compared to WWTPs and could result in an important contribution to a city's carbon footprint. Further work needs to be done to assess the gas production along the entire sewer network, which can result in very different emission factors depending on the sewer components.
\end{abstract}

Keywords: Sewers, Greenhouse Gases, Urban Wastewater, $\mathrm{N}_{2} \mathrm{O}, \mathrm{CH}_{4}$, sustainability

\section{Introduction}


Currently more than $50 \%$ of the world's population resides in urban areas and is expected to increase to $70 \%$ by 2050 [1]. Due to this urban intensification, more infrastructures will be required, in particular the ones related to water supply and sanitation. Hence, the sustainable management of the entire urban water cycle is a key point that needs to be addressed in order to meet the water needs of the citizens. Furthermore, an efficient water cycle management can potentially contribute to the local climate action plans for reduction of greenhouse gas (GHG) emissions.

The urban water cycle includes water abstraction, drinking water treatment, water transport and distribution, water use, sewerage and rainwater transport and wastewater treatment. Due to the wastewater degradation and energy requirements, each phase contributes to the urban carbon footprint, but most of the attention has been placed on direct emissions from wastewater treatment plants (WWTPs). WWTPs have been recognised as a significant source of gaseous compounds [2], where the biological treatments result in $\mathrm{GHG}$ emissions of carbon dioxide $\left(\mathrm{CO}_{2}\right)$, methane $\left(\mathrm{CH}_{4}\right)$ and nitrous oxide $\left(\mathrm{N}_{2} \mathrm{O}\right)$, as well as hydrogen sulphide $\left(\mathrm{H}_{2} \mathrm{~S}\right)$, among many others.

The Fourth Assessment Report of the Intergovernmental Panel on Climate Change (IPCC) has established guidelines for quantifying GHG emissions in WWTPs [3]. Based on these methodologies, the European Commission [4] reported that $9 \%$ and $3 \%$ of the world's $\mathrm{CH}_{4}$ and $\mathrm{N}_{2} \mathrm{O}$ emissions figures come from WWTPs, respectively. However, there is a high degree of uncertainty in these figures given the rapid growth and urbanisation in developing countries. Furthermore, these values could be underestimated since they ignore the emissions taking place in sewer networks transporting the wastewater to the WWTPs. Sewer networks act as biological plug-flow reactors with high hydraulic retention time (HRT), which can be equal or higher than that at the WWTP depending on the configuration of the network [5]. Depending on the type of sewer (gravity or pressurised) or the type of constructive element, GHG such as $\mathrm{CO}_{2}, \mathrm{~N}_{2} \mathrm{O}, \mathrm{CH}_{4}$, as well as $\mathrm{H}_{2} \mathrm{~S}$ can result from aerobic, anoxic or anaerobic environments. [6] (Supporting Information 1). For a more detailed description of the sewer elements and biological processes leading to emissions, we recommend $[5,7,8]$.

Emissions of $\mathrm{CH}_{4}$ and $\mathrm{H}_{2} \mathrm{~S}$ from sewers have received a lot more attention than $\mathrm{N}_{2} \mathrm{O}$ and $\mathrm{CO}_{2}$ given their safety, toxicity, and corrosion issues [9-15]. According to the IPCC, $\mathrm{CH}_{4}$ has a Global Warming Potential (GWP) 25 times higher than $\mathrm{CO}_{2}$ in a 100-year time horizon [16]. $\mathrm{H}_{2} \mathrm{~S}$ has a Human Toxicity Potential of $0.22 \mathrm{~kg}$ of 1.4 dichlorobenzene (1,4-DB) eq. $/ \mathrm{kg} \mathrm{H}_{2} \mathrm{~S}$ [17], and additionally, it can oxidize to sulphuric acid, resulting in the deterioration of sewer network elements [18], especially concrete pipes [19].

However, $\mathrm{N}_{2} \mathrm{O}$ could be considered of higher concern than $\mathrm{CH}_{4}$ in terms of GWP, being 298 times greater than that of $\mathrm{CO}_{2}[16]$ and having a lifetime of 120 years in the atmosphere [20]. In addition, this gas is also a source of $\mathrm{NO}$ and $\mathrm{NO}_{2}$, which participate in catalytic cycles that deplete ozone [16]. Given the Ozone Depletion Potential (ODP) and GWP of $\mathrm{N}_{2} \mathrm{O}$, it is important to determine its contribution to the carbon footprint of sewers and, therefore, to the entire urban water cycle. In spite of its importance, to the best of our knowledge very few studies have been specifically dedicated to determine $\mathrm{N}_{2} \mathrm{O}$ production in sewer networks [21-23] compared to the existent literature on the production of this gas in WWTP [24-28].

In this sense, the purpose of this paper is to offer a critical overview of the published studies regarding $\mathrm{CH}_{4}, \mathrm{H}_{2} \mathrm{~S}$ and $\mathrm{N}_{2} \mathrm{O}$ generation in sewer networks. The aim is to determine the research gaps that need to be explored, in particular regarding the type of sewer system and the main 
parameters related to the quantification of these particular gases. In order to address some of the research gaps, two case studies of the sewer networks of two medium-sized Spanish cities (Betanzos in Atlantic area and Calafell in Mediterranean area) are presented, where the generation of $\mathrm{CH}_{4}, \mathrm{H}_{2} \mathrm{~S}$ and $\mathrm{N}_{2} \mathrm{O}$ were quantified. These case studies serve to analyze the contribution of sewers to the urban water cycle footprint. Furthermore, in view of the literature review and the results of the case studies presented, we make several suggestions to guide future efforts in quantifying GHG emissions from sewer networks. 


\section{Recent studies on GHG and $\mathrm{H}_{2} \mathrm{~S}$ production in sewers}

A compilation of previous literature quantifying $\mathrm{CH}_{4}, \mathrm{H}_{2} \mathrm{~S}$ and $\mathrm{N}_{2} \mathrm{O}$ in sewer networks is presented in Table 1. Studies that focused on WWTP but provide a quantification of the emissions at the influent of the WWTP were also included. When possible, and based on data provided by the authors, we have converted the emission factors to $\mu \mathrm{g} \mathrm{L}^{-1}$ (given in parentheses in Table 1), to facilitate comparison amongst studies. Comparison of the reported emission factors is not straight forward because data are reported in diverse units, different analytical and sampling methods are employed, and sampling conditions are not always reported. Calculations for unit conversions are provided in Supporting information 2. The fourth column provides the sewer component considered (rising or gravity sewer, manhole, wet well or pumping station, influent to WWTP) and identifies which studies are conducted using data generated in the lab or in field sampling campaigns. A description of the methods used, the sampling conditions, and the main findings is also given. The latter are further discussed in the following paragraphs.

Emissions are often reported in different units and some assumptions were made in order to convert the values to $\mu \mathrm{g} \mathrm{L}^{-1}$ since the studies did not provide all the data required for calculations. For example, Debruyn et al. [21] reported $23 \mu \mathrm{g}$ of $\mathrm{N}_{2} \mathrm{O}$ per gram of suspended solids. In order to relate this result to $1 \mathrm{~L}$ of wastewater, a range of $270-550 \mathrm{mg}$ of suspended solids per litre was applied [29] and the final converted values were 6.1-12.7 $\mu \mathrm{g}$ of $\mathrm{N}_{2} \mathrm{O} \mathrm{L}^{-1}$. In contrast, Clemens and Haas [22] gave an emission factor of $3.5 \mathrm{~g}$ of $\mathrm{N}_{2} \mathrm{O}$ per person per year, and data on the population of Bayreuth served by the WWTP at the time of the study was not reported as it was a key parameter in determining the concentration. In other cases, an emission rate at the entrance of the

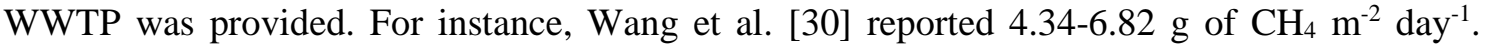
According to data found in the study, there was an emitting surface of $45 \mathrm{~m}^{2}$ and a daily wastewater production of $450 \mathrm{~m}^{3} \mathrm{day}^{-1}$ was assumed. At the end, a $\mathrm{CH}_{4}$ concentration of 434-682 $\mu \mathrm{g} \mathrm{L}^{-1}$ was obtained. To consult all the conversions see Supporting information 2. 
Table 1 Recent studies of GHG and $\mathrm{H}_{2} \mathrm{~S}$ in sewers. COD: Chemical Oxygen Demand, HRT: Hydraulic Retention Time. DO: Dissolved Oxygen. A/V: biofilm area-to-liquid volume (A/V) ratio. TSS: Total Suspended Solids. TN: Total Nitrogen. BOD 5 : Biological Oxygen Demand at 5 days. n/m: not measured. n/a: not available. VFA: Volatile Fatty Acids. SBR: Sulphate Reducing Bacteria. The figures reported in the table are shown as given by the authors. In brackets the reader can find the compound concentrations in the gas phase, details about calculations are in supporting information 2.

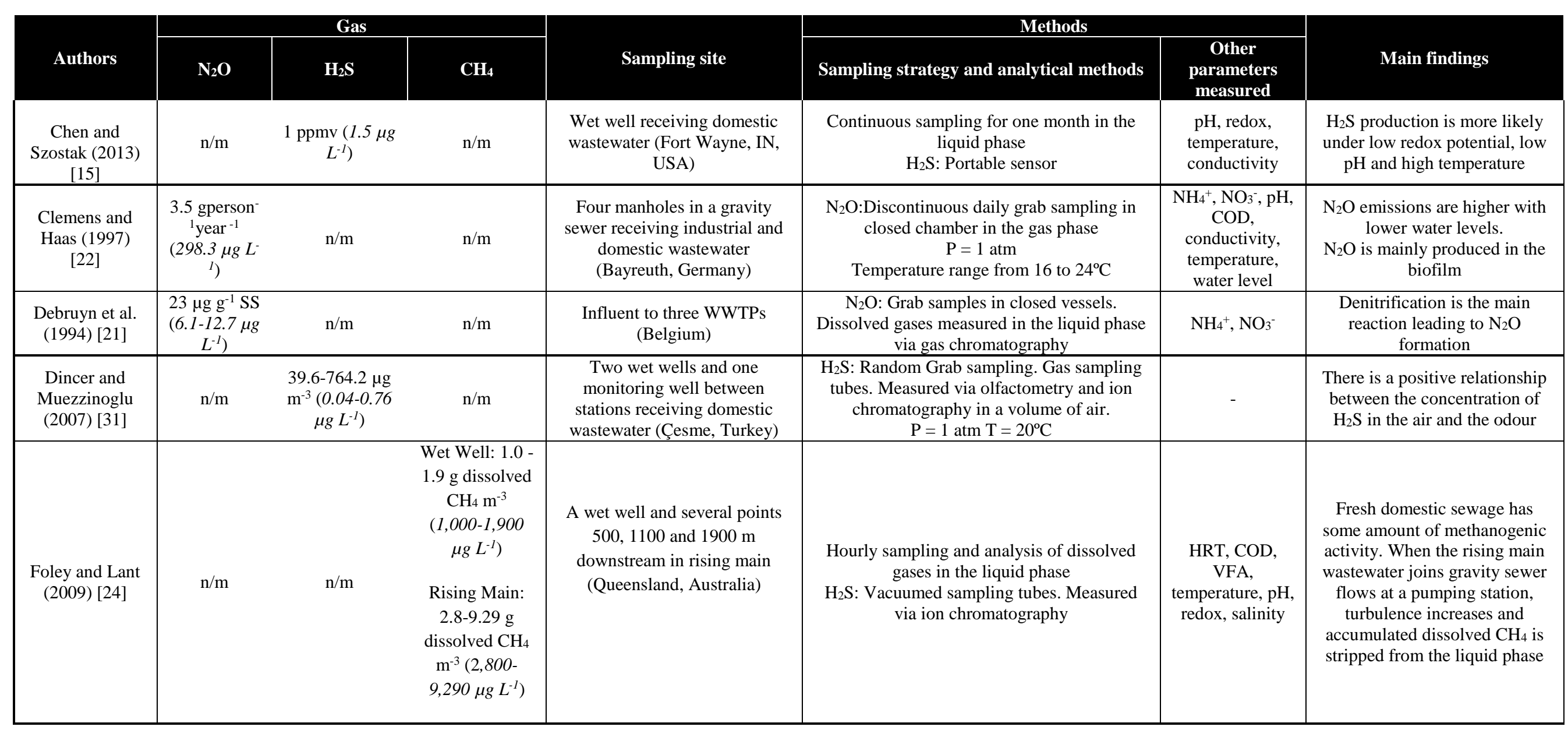




\begin{tabular}{|c|c|c|c|c|c|c|c|}
\hline \multirow[b]{2}{*}{ Authors } & \multicolumn{3}{|c|}{ Gas } & \multirow[b]{2}{*}{ Sampling site } & \multicolumn{2}{|l|}{ Methods } & \multirow[b]{2}{*}{ Main findings } \\
\hline & $\mathbf{N}_{2} \mathrm{O}$ & $\mathbf{H}_{2} \mathbf{S}$ & $\mathrm{CH}_{4}$ & & Sampling strategy and analytical methods & $\begin{array}{c}\text { Other } \\
\text { parameters } \\
\text { measured }\end{array}$ & \\
\hline $\begin{array}{l}\text { Guisasola et al. } \\
\text { (2008) [12] }\end{array}$ & $\mathrm{n} / \mathrm{m}$ & $\begin{array}{c}\text { Rising Mains: } \\
7-12 \mathrm{~g} \mathrm{~S} \mathrm{~m}^{-3} \\
(7,000-12,000 \\
\left.\mu g L^{-1}\right) \\
\text { Lab: } 6-14 \mathrm{~g} \mathrm{~S} \\
\mathrm{~m}^{-3}(6,000- \\
\left.14,000 \mu \mathrm{g} \mathrm{L}^{-1}\right)\end{array}$ & $\begin{array}{c}\text { Rising Mains: } \\
\text { 20-120g COD } \\
\mathrm{m}^{-3}(5,000- \\
\left.30,000 \mu \mathrm{g} \mathrm{L^{-1 }}\right) \\
\text { Lab: } 30-120 \mathrm{~g} \\
\text { COD m}{ }^{-3} \\
(7,500-30,000 \\
\left.\mu g L^{-1}\right)\end{array}$ & $\begin{array}{l}\text { Field: Two rising mains } \\
\text { collecting domestic wastewater } \\
\text { (Gold Coast, Australia) } \\
\text { Lab: Four reactors in series to } \\
\text { simulate rising main }\end{array}$ & $\begin{array}{l}\text { Daily online sampling in the liquid phase } \\
\mathrm{H}_{2} \mathrm{~S} \text { : Soluble sulphur species measured via } \\
\text { ion chromatography } \\
\mathrm{CH}_{4} \text { : Vacuumed sampling tubes. Measured } \\
\text { via ion chromatography }\end{array}$ & $\begin{array}{l}\text { COD, VFA, } \\
\text { HRT }\end{array}$ & $\begin{array}{l}\text { Longer } \mathrm{HRT}_{\mathrm{T}} \text { derives in greater } \\
\mathrm{CH}_{4} \text { production. } \\
\mathrm{CH}_{4} \text { production influences } \mathrm{H}_{2} \mathrm{~S} \\
\text { emissions due to bacteria } \\
\text { competition for the same } \\
\text { electron donor }\end{array}$ \\
\hline $\begin{array}{l}\text { Guisasola et al. } \\
\text { (2009) [32] }\end{array}$ & $\mathrm{n} / \mathrm{m}$ & $\begin{array}{c}\text { Rising Main: } \\
4-7 \mathrm{mg} \mathrm{S} \mathrm{L}^{-1} \\
(4,000-7,000 \\
\left.\mu g L^{-1}\right) \\
\text { Lab: } 2-13 \\
\text { mg S L- } \\
\begin{array}{c}1(2,000-13,000 \\
\left.\mu g L^{-1}\right)\end{array}\end{array}$ & 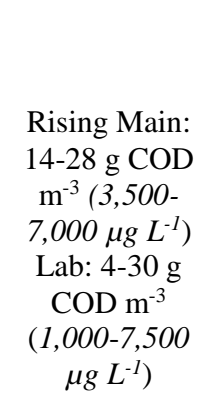 & $\begin{array}{l}\text { Field: rising main (Gold Coast, } \\
\text { Australia) } \\
\text { Lab: Four reactors in series to } \\
\text { simulate rising main }\end{array}$ & $\begin{array}{l}\text { Hourly samples for ten hours in the liquid } \\
\text { phase } \\
\mathrm{H}_{2} \mathrm{~S} \text { : Soluble sulphur species measured via } \\
\quad \text { ion chromatography } \\
\mathrm{CH}_{4} \text { : Vacuumed sampling tubes. Measured } \\
\text { via ion chromatography }\end{array}$ & $\begin{array}{l}\text { COD, VFA, } \\
\text { HRT, A/V ratio }\end{array}$ & $\begin{array}{l}\text { Influence of sewer design: } \\
\text { Longer HRT and larger A/V } \\
\text { ratio derive in greater } \mathrm{CH}_{4} \\
\text { production }\end{array}$ \\
\hline $\begin{array}{l}\text { Gutierrez et al. } \\
\text { (2014) [33] }\end{array}$ & $\mathrm{n} / \mathrm{m}$ & $\begin{array}{c}\text { Downstream: } 6 \\
\mathrm{~g} \mathrm{~S} \mathrm{~m}^{-3}(6,000 \\
\left.\mu g L^{-1}\right) \\
\text { Lab: } 7 \mathrm{~g} \mathrm{~S} \mathrm{~m}^{-3} \\
\mathrm{~h}^{-1}\left(\begin{array}{c}\left(7,000 \mu g L^{-}\right. \\
1\end{array}\right)\end{array}$ & $\begin{array}{c}\text { Downstream: } \\
3.1 \mathrm{~g} \mathrm{CH}_{4} \mathrm{~m}^{-3} \\
\left(3,100 \mu g L^{-1}\right) \\
\text { Wet well: } \\
0.2 \mathrm{~g} \mathrm{~m}^{-3}(200 \\
\left.\mu g L^{-1}\right) \\
\text { Lab: } 7.5 \mathrm{~g} \mathrm{CH}_{4} \\
\mathrm{~m}^{-3} \mathrm{~h}^{-1}(7,500 \\
\left.\mu g L^{-1}\right) \\
\end{array}$ & $\begin{array}{l}\text { Field: Wet well and } 828 \mathrm{~m} \\
\text { downstream in rising main } \\
\text { (Gold Coast, Australia) } \\
\text { Lab: Four reactors to simulate } \\
\text { rising mains }\end{array}$ & $\begin{array}{c}\text { Sampling tests for two hours and six hours in } \\
\text { the liquid phase } \\
\mathrm{H}_{2} \mathrm{~S} \text { : Soluble sulphur species measured via } \\
\text { ion chromatography } \\
\mathrm{CH}_{4} \text { : Vacuumed sampling tubes. Measured } \\
\text { via ion chromatography }\end{array}$ & COD, pH, TSS & $\begin{array}{l}\text { Increasing the } \mathrm{pH} \text { reduces the } \\
\mathrm{H}_{2} \mathrm{~S} \text { and } \mathrm{CH}_{4} \text { emissions }\end{array}$ \\
\hline $\begin{array}{l}\text { Jiang et al. } \\
(2009)[34]\end{array}$ & $\mathrm{n} / \mathrm{m}$ & $\begin{array}{c}2.8 \mathrm{mg} \mathrm{S} \mathrm{L}^{-} \\
{ }^{1}\left(2800 \mu g \mathrm{~L}^{-1}\right)\end{array}$ & $\mathrm{n} / \mathrm{m}$ & $\begin{array}{c}\text { Four lab reactors in series to } \\
\text { simulate gravity sewer fed with } \\
\text { domestic wastewater by gravity } \\
\text { (Australia) }\end{array}$ & $\begin{array}{l}\mathrm{H}_{2} \mathrm{~S} \text { species: Soluble sulphur species } \\
\text { measured in the liquid phase via ion } \\
\text { chromatography }\end{array}$ & $\mathrm{NO}_{3}^{-}$ & $\begin{array}{l}\text { Nitrate dosing reduces sulphide } \\
\text { formation }\end{array}$ \\
\hline
\end{tabular}




\begin{tabular}{|c|c|c|c|c|c|c|c|}
\hline \multirow[b]{2}{*}{ Authors } & \multicolumn{3}{|c|}{ Gas } & \multirow[b]{2}{*}{ Sampling site } & \multicolumn{2}{|l|}{ Methods } & \multirow[b]{2}{*}{ Main findings } \\
\hline & $\mathrm{N}_{2} \mathrm{O}$ & $\mathbf{H}_{2} \mathbf{S}$ & $\mathrm{CH}_{4}$ & & Sampling strategy and analytical methods & $\begin{array}{l}\text { Other } \\
\text { parameters } \\
\text { measured }\end{array}$ & \\
\hline $\begin{array}{l}\text { Jiang et al. } \\
\text { (2010) [35] }\end{array}$ & $\mathrm{n} / \mathrm{m}$ & $\begin{array}{l}\text { Downstream: } \\
5-7 \mathrm{~g} \mathrm{~S} \mathrm{~m}^{-3} \\
(5,000-7,000 \\
\left.\mu g L^{-1}\right) \\
\text { Wet well: }<1 \mathrm{~g} \\
\mathrm{~S} \mathrm{~m} \mathrm{~m}^{-3}(<1,000 \\
\left.\quad \mu g L^{-1}\right)\end{array}$ & $\begin{array}{c}\text { Downstream: } \\
\text { 17-22 g COD } \\
\mathrm{m}^{-3}(4,250- \\
\left.5,500 \mu g L^{-1}\right) \\
\text { Wet well: } 3-4 \mathrm{~g} \\
\text { COD m }{ }^{-3}(750- \\
\left.1,000 \mu g L^{-1}\right) \\
\text { Lab: } 65-71 \mathrm{~g} \\
\text { COD m } \\
(16,250-17,750 \\
\left.\mu g L^{-1}\right) \\
\end{array}$ & $\begin{array}{l}\text { Field: wet well and } 828 \mathrm{~m} \\
\text { downstream in rising main } \\
\text { (Gold Coast, Australia) } \\
\text { Lab: Four reactors to simulate } \\
\text { rising mains }\end{array}$ & $\begin{array}{l}\text { Samples taken at the beginning and end of a } \\
\text { 6-h cycle each day and measured in the liquid } \\
\text { phase } \\
\mathrm{H}_{2} \mathrm{~S} \text { : Soluble sulphur species measured via } \\
\text { ion chromatography. Online sensor used in } \\
\text { field analysis } \\
\mathrm{CH}_{4} \text { : Vacuumed sampling tubes. Measured } \\
\text { via ion chromatography }\end{array}$ & $\begin{array}{l}\mathrm{COD}, \mathrm{VFA} \\
\mathrm{NO}_{2}^{-}, \mathrm{NH}_{3}\end{array}$ & $\begin{array}{l}\text { Applying nitrite in sewer } \\
\text { systems inhibits the sulphate } \\
\text { reduction and methane } \\
\text { production }\end{array}$ \\
\hline $\begin{array}{l}\text { Lahav et al. } \\
\text { (2006) [11] }\end{array}$ & $\mathrm{n} / \mathrm{m}$ & $\begin{array}{l}20-25 \mathrm{mg} \mathrm{S} \mathrm{L}^{-1} \\
(20,000-25,000 \\
\left.\quad \mu g L^{-1}\right)\end{array}$ & $\mathrm{n} / \mathrm{m}$ & $\begin{array}{l}\text { Experimental gravity sewer } \\
\text { pipe }(27 \mathrm{~m}) \text { with aeration } \\
\text { windows (lab-scale analysis) }\end{array}$ & $\begin{array}{l}\mathrm{H}_{2} \mathrm{~S} \text { : Continuous sampling. Dissolved } \\
\text { sulphide sampled in the liquid phase at the } \\
\text { end of the stream and measured with a } \\
\text { colorimetric method }\end{array}$ & $\begin{array}{c}\text { Temperature, } \\
\mathrm{pH}, \text { flow rate, } \\
\text { hydraulic depth, } \\
\text { velocity } \\
\end{array}$ & $\begin{array}{l}\mathrm{H}_{2} \mathrm{~S} \text { emissions are dependent on } \\
\text { the mean velocity gradient in } \\
\text { gravity flow (predictive } \\
\text { equation) }\end{array}$ \\
\hline $\begin{array}{l}\text { Mohanakrishnan et } \\
\text { al. (2008) [36] }\end{array}$ & $\mathrm{n} / \mathrm{m}$ & $\begin{array}{l}10-25 \mathrm{~g} \mathrm{~S} \mathrm{~m}^{-3} \\
(10,000-25,000 \\
\left.\quad \mu g L^{-1}\right)\end{array}$ & $\mathrm{n} / \mathrm{m}$ & $\begin{array}{l}\text { Lab-scale sewer reactor fed } \\
\text { with domestic wastewater } \\
\text { (Gold Coast, Australia) }\end{array}$ & $\begin{array}{c}24 \mathrm{~h} \text { online measurements in the liquid phase } \\
\text { on selected days } \\
\mathrm{H}_{2} \mathrm{~S} \text { : Dissolved sulphur and nitrogen species } \\
\text { analysed with ion chromatography } \\
\mathrm{CH}_{4} \text { : Measured via gas chromatography }\end{array}$ & $\mathrm{NO}_{3}^{-}$ & $\begin{array}{l}\text { Nitrate reduces sulphide levels } \\
\text { by } 66 \% \text {, but it is not toxic or } \\
\text { inhibitory to SRB activity. } \\
\text { Nitrate also reduces methane } \\
\text { formation in rising mains } \\
\end{array}$ \\
\hline $\begin{array}{l}\text { Nielsen et al. } \\
\text { (2005) [37] }\end{array}$ & $\mathrm{n} / \mathrm{m}$ & $\begin{array}{l}<0.2 \mathrm{mg} \mathrm{S} \mathrm{L}^{-1} \\
\left(<200 \mu \mathrm{g} \mathrm{L}^{-1}\right)\end{array}$ & $\mathrm{n} / \mathrm{m}$ & $\begin{array}{c}\text { Domestic wastewater collected } \\
\text { at the influent pumping station } \\
\text { of a WWTP (Bennekom, The } \\
\text { Netherlands) }\end{array}$ & $\begin{array}{l}\mathrm{H}_{2} \mathrm{~S} \text { : Daily water samples taken during } \\
\text { several weeks. Dissolved sulphide } \\
\text { concentration analysed according to the } \\
\text { methylene blue method, and sulphate and } \\
\text { nitrate with ion chromatography } \\
\end{array}$ & $\begin{array}{l}\text { Addition of } \\
\text { Fe(III) }\end{array}$ & $\begin{array}{l}\text { Addition of Fe(III) to anaerobic } \\
\text { wastewater in the presence of } \\
\text { excess sulphide resulted in the } \\
\text { oxidation of dissolved sulphide } \\
\text { to form FeS }\end{array}$ \\
\hline $\begin{array}{l}\text { Othman and } \\
\text { Mortezania } \\
(2010)[38]\end{array}$ & $\mathrm{n} / \mathrm{m}$ & $\begin{array}{c}11 \mathrm{ppmv}(15.6 \\
\left.\mu g L^{-1}\right)\end{array}$ & $\mathrm{n} / \mathrm{m}$ & $\begin{array}{l}\text { Three manholes in a gravity } \\
\text { sewer receiving domestic } \\
\text { wastewater (Mashhad, Iran) }\end{array}$ & $\begin{array}{l}\text { Several tests: } 1 \text { time/ } 2 \text { times/ } 3 \text { times in } 30 \\
\text { days } \\
\text { in the gas phase } \\
\mathrm{H}_{2} \mathrm{~S} \text { : MultiGas detector with special sensors }\end{array}$ & $\mathrm{O}_{2}$, velocity & $\begin{array}{l}\text { Water flushing technique } \\
\text { reduces the } \mathrm{H}_{2} \mathrm{~S} \text { emissions }\end{array}$ \\
\hline $\begin{array}{l}\text { Porro et al. } \\
\text { (2011) [39] }\end{array}$ & $\mathrm{n} / \mathrm{m}$ & $\mathrm{n} / \mathrm{m}$ & $\begin{array}{l}\text { WWTP } \\
\text { influent: }\end{array}$ & $\begin{array}{c}\text { Simulations with a realistic } \\
\text { gravity and rising sewer } \\
\text { network }\end{array}$ & $\begin{array}{l}\text { Tests performed using the model developed } \\
\text { by Guisasola et al (2009) }\end{array}$ & - & $\begin{array}{l}\text { Sewer design influences } \mathrm{CH}_{4} \\
\text { emissions }\end{array}$ \\
\hline
\end{tabular}




\begin{tabular}{|c|c|c|c|c|c|c|c|}
\hline \multirow[b]{2}{*}{ Authors } & \multicolumn{3}{|c|}{ Gas } & \multirow[b]{2}{*}{ Sampling site } & \multicolumn{2}{|l|}{ Methods } & \multirow[b]{2}{*}{ Main findings } \\
\hline & $\mathbf{N}_{2} \mathrm{O}$ & $\mathbf{H}_{2} \mathbf{S}$ & $\mathrm{CH}_{4}$ & & Sampling strategy and analytical methods & $\begin{array}{c}\text { Other } \\
\text { parameters } \\
\text { measured }\end{array}$ & \\
\hline & & & $\begin{array}{l}12 \mathrm{~g} \mathrm{COD} \mathrm{m}^{-3} \\
\left(2,999 \mu \mathrm{g} \mathrm{L}^{-1}\right)\end{array}$ & & & & \\
\hline $\begin{array}{l}\text { Sharma et al. } \\
\text { (2008) [13] }\end{array}$ & $\mathrm{n} / \mathrm{m}$ & $\begin{array}{c}>5 \mathrm{~g} \mathrm{~S} \mathrm{~m}^{-3} \\
\left(>5,000 \mu \mathrm{g} \mathrm{L}^{-1}\right)\end{array}$ & $\mathrm{n} / \mathrm{m}$ & $\begin{array}{l}\text { Two rising mains receiving } \\
\text { domestic wastewater (Gold } \\
\text { Coast, Australia) }\end{array}$ & $\begin{array}{l}\text { Hourly sampling for } 8-29 \mathrm{~h} \text { in the } \\
\text { liquid phase } \\
\mathrm{H}_{2} \mathrm{~S} \text { : Soluble sulphur species measured via } \\
\text { ion chromatography }\end{array}$ & $\begin{array}{l}\text { COD, VFA, } \\
\text { flow rate, DO }\end{array}$ & $\begin{array}{l}\text { Spatial and temporal variations } \\
\text { in sulphide, sulphate and VFA } \\
\text { concentrations. Oxygen } \\
\text { injection at the end of the sewer } \\
\text { is more efficient to reduce the } \\
\text { emissions } \\
\end{array}$ \\
\hline $\begin{array}{l}\text { Short et al. } \\
\text { (2014) [23] }\end{array}$ & $\begin{array}{l}1.6-1.7 \mathrm{~g} \\
\text { person-1 year } \\
-1(7.4-9.8 \\
\left.\mu g L^{-1}\right) \\
\end{array}$ & $\mathrm{n} / \mathrm{m}$ & $\mathrm{n} / \mathrm{m}$ & $\begin{array}{l}\text { Influent to three WWTPs } \\
\text { receiving domestic, commercial } \\
\text { and industrial wastewater (New } \\
\text { South Wales, Australia) }\end{array}$ & $\begin{array}{l}\text { Monthly samples for eight months in the } \\
\text { liquid phase } \\
\mathrm{N}_{2} \mathrm{O} \text { : Dissolved } \mathrm{N}_{2} \mathrm{O} \text { extracted using a single- } \\
\text { phase, syringe-based static headspace } \\
\text { protocol }\end{array}$ & $\begin{array}{l}\mathrm{TN}, \mathrm{NH}_{4}^{+}-\mathrm{N} \\
\mathrm{COD}, \mathrm{BOD}_{5} \\
\text { TSS, pH, } \\
\text { temperature }\end{array}$ & $\begin{array}{c}\text { Underground gravity sewers are } \\
\text { an important source of } \mathrm{N}_{2} \mathrm{O} \text { and } \\
\text { the emission factor is } \\
\text { comparable to secondary } \\
\text { processes in WWTPs } \\
\end{array}$ \\
\hline $\begin{array}{l}\text { Wang et al. } \\
\text { (2011) [30] }\end{array}$ & $\mathrm{n} / \mathrm{m}$ & $\mathrm{n} / \mathrm{m}$ & $\begin{array}{l}\text { Methane flux } \\
4.34-6.82 \mathrm{~g} \mathrm{~m}^{-2} \\
\text { day }^{-1}(434-682 \\
\left.\mu g L^{-1}\right) \\
\end{array}$ & $\begin{array}{l}\text { Influent to WWTP (Jinan, } \\
\text { China) }\end{array}$ & $\begin{array}{c}\mathrm{CH}_{4} \text { : Wastewater samples three days a week, } \\
\text { space-gas method and calculations based on } \\
\text { Henry's law and gas chromatography in the } \\
\text { liquid phase }\end{array}$ & $\begin{array}{c}\mathrm{DO} \\
\text { temperature, } \mathrm{pH}, \\
\mathrm{COD}, \mathrm{NO}_{2}^{-} \\
\mathrm{NO}_{3}^{-} \\
\end{array}$ & $\begin{array}{c}\text { Main factors that influence } \mathrm{CH}_{4} \\
\text { emissions are } \mathrm{DO}, \mathrm{pH}, \\
\text { temperature, } \mathrm{COD}, \mathrm{NO}_{2}^{-} \text {and } \\
\qquad \mathrm{NO}_{3}^{-} \\
\end{array}$ \\
\hline $\begin{array}{l}\text { Willis et al. } \\
\text { (2010) [40] }\end{array}$ & $\mathrm{n} / \mathrm{m}$ & $\mathrm{n} / \mathrm{m}$ & $\begin{array}{l}0-3,300 \mathrm{~g} \mathrm{~m}^{-3} \\
(0-3,300,000 \\
\left.\quad \mu g L^{-1}\right)\end{array}$ & $\begin{array}{l}64 \text { wet wells (DeKalb County, } \\
\text { GA, USA) }\end{array}$ & $\begin{array}{c}\mathrm{CH}_{4} \text { : Monthly samples in the gas phase for a } \\
\text { year. Unventilated stations (63): gas samples } \\
\text { from above the liquid surface, in the middle } \\
\text { of the wet well's headspace and below the } \\
\text { access } \\
\text { Ventilated station (1): samples from } \\
\text { discharge header } \\
\text { Temperature range from } 13 \text { to } 27^{\circ} \mathrm{C} \\
\mathrm{P}=1 \mathrm{~atm} \\
\end{array}$ & $\begin{array}{l}\text { Temperature, } \\
\mathrm{H}_{2} \mathrm{~S}, \mathrm{CO}_{2}, \mathrm{CO}\end{array}$ & $\begin{array}{l}\text { Influence of seasonality: In } \\
\text { summer, more emissions might } \\
\text { take place than in winter }\end{array}$ \\
\hline $\begin{array}{l}\text { Yongsiri et al. } \\
\text { (2005) [10] }\end{array}$ & $\mathrm{n} / \mathrm{m}$ & $\begin{array}{c}3-8 \mathrm{~g} \mathrm{~S} \mathrm{~m}^{-3} \\
(3,000-8,000 \\
\left.\mu g L^{-1}\right)\end{array}$ & $\mathrm{n} / \mathrm{m}$ & $\begin{array}{c}\text { Two gravity sewer lines } \\
\text { collecting domestic wastewater } \\
\text { (Frejlev and Hasseris, } \\
\text { Denmark) } \\
\end{array}$ & $\begin{array}{l}\mathrm{H}_{2} \mathrm{~S} \text { : Daily online samples in the liquid phase } \\
\text { for six months. Wastewater samples. Mass- } \\
\text { transfer coefficient and Henry's law constant } \\
\text { determined with closed vessels } \\
\end{array}$ & $\begin{array}{c}\text { COD, } \\
\text { turbulence, DO }\end{array}$ & $\begin{array}{l}\text { Impurities in domestic } \\
\text { wastewater reduce the emission } \\
\text { rate of } \mathrm{H}_{2} \mathrm{~S}(60 \% \text { of the rate } \\
\text { measured in deionised water) }\end{array}$ \\
\hline
\end{tabular}


As shown in Table 1, several authors have studied $\mathrm{CH}_{4}$ formation in sewers. Methane concentrations for wet wells at pumping stations previous to WWTP ranged from $200 \mu \mathrm{g} \mathrm{L}^{-1}$ in Gold Coast (Australia) [33] to 3,300,000 $\mu \mathrm{g} \mathrm{L}^{-1}$ in DeKalb County (Georgia, United States) [40]. In the case of rising mains, most studies were conducted in the Gold Coast (Australia), and methane concentrations ranged from 2,800 to $30,000 \mu \mathrm{g} \mathrm{L}^{-1}[12,24,32]$. Nevertheless, the authors do not specifically determine which conditions were present in each sampling site (i.e., aerobic, anaerobic or anoxic) and a relationship between aeration and gas formation cannot be established.

Some of these studies further determined that dissolved oxygen inhibits methane formation $[13,30,32]$, whereas a neutral $\mathrm{pH}(7.0-7.2)$ resulted to be optimal for methanogens to produce $\mathrm{CH}_{4}$ [30]. Other factors reported to influence $\mathrm{CH}_{4}$ formation are: biofilm area-to-liquid volume (A/V) ratio, HRT, amount of nitrite and nitrate present, $\mathrm{pH}$, and temperature (in winter less emissions take place). Furthermore it was found that methane emissions are not necessarily emitted to the air where they are formed. Instead, $\mathrm{CH}_{4}$ emissions (as well as all other gases) are normally present where the sewer network suffers a pressure loss, typically resulting from turbulence caused by the flow of a rising main joining a gravity sewer $[12,24,33,35,39,40]$.

The studies addressing $\mathrm{H}_{2} \mathrm{~S}$ formation also show significant variability. Concentrations of $\mathrm{H}_{2} \mathrm{~S}$ range from $0.04 \mu \mathrm{g} \mathrm{L}^{-1}$ in a pumping station [31] to $7700 \mu \mathrm{g} \mathrm{L}^{-1}$ in a wet well of a pumping station [35] and $11,000 \mu \mathrm{g} \mathrm{L}^{-1}$ in a gravity sewer [38]. Hydrogen sulphide is observed to be released in areas with slow flow rates, insufficient re-aeration (low oxygen-water transfer), relatively high temperature, low pH, and high turbulence [15,41-44]. Sharma et al. [13] also added that high $\mathrm{HRT}$ and small A/V ratio are associated with high $\mathrm{H}_{2} \mathrm{~S}$ production.

Consequently, in the prevention of these emissions, these factors must be considered. For instance, raising the $\mathrm{pH}$ has become a standard method for reducing $\mathrm{H}_{2} \mathrm{~S}$ in sewers. Dissolved oxygen (DO) levels above $0.5 \mathrm{mg} \mathrm{L}^{-1}$ can generally prevent sulphide occurrence by avoiding anaerobic conditions [45]. Nitrates and nitrites were also found to inhibit methane and sulphide formation because they are toxic to Sulphate Reducing Bacteria (SRB) and Methanogenic Bacteria (MB) $[30,35,36,43]$.

Regarding $\mathrm{N}_{2} \mathrm{O}$ production, Debruyn et al. [21] and Short et al. [23] calculated the $\mathrm{N}_{2} \mathrm{O}$ gas concentrations at the influent to several WWTPs to be 6.1 to $9.8 \mu \mathrm{g} \mathrm{L}^{-1}$ in Belgium and Australia, respectively. Clemens and Haas [22] reported $\mathrm{N}_{2} \mathrm{O}$ concentrations of $298 \mu \mathrm{g} \mathrm{L}^{-1}$ in a gravity sewer of Bayreuth, Germany, which received both industrial and domestic wastewater. They noted that the lower the wastewater level in the gravity sewer (bigger head space), the higher $\mathrm{N}_{2} \mathrm{O}$ emissions are.

Nitrous oxide generation processes have been found to depend on parameters such as carbon to nitrogen ratio and the organic loading rate, the aeration regime (oxic-anoxic-anaerobic cycling), the $\mathrm{pH}$, the substrates concentration $\left(\mathrm{NH}_{4}{ }^{+}, \mathrm{NO}_{2}{ }^{-}, \mathrm{NO}_{3}{ }^{-}\right)$and the intermediates $\left(\mathrm{NO}_{2}, \mathrm{NO}\right.$ and free nitrous acid), as well as the abundance and activity of $\mathrm{N}_{2} \mathrm{O}$-producing microorganisms [23$25,46]$. Experiments in WWTP revealed that nitrite increases the $\mathrm{N}_{2} \mathrm{O}$ emissions both during nitrification and denitrification [25] under organic carbon limiting conditions [47]. In areas where nitrate accumulates, high amounts of $\mathrm{N}_{2} \mathrm{O}$ are expected, as nitrous oxide is a worse electron acceptor and cannot compete for electrons with nitrate. Aeration also plays a key role in the reduction of $\mathrm{N}_{2} \mathrm{O}$ emissions, given that nitrite does not accumulate when the sewer system is intermittently aerated [48]. Regarding $\mathrm{pH}$, the optimum for the growth of bacteria ranges between 7 and 8 [46]; hence, greater emissions would be expected under these conditions. 
Albeit these studies are too varied to be able to specify an emission factor with wide applicability, they do serve to point out that the emissions are significant and comparable to those occurring in a WWTP. Default concentration values used for country-wide GHG reporting under the IPCC protocol for WWTP range between 1.6 (primary treatment) and $31 \mu \mathrm{g} \mathrm{L}^{-1}$ (secondary treatment) [49]. In general, there is a limited amount of studies quantifying sewer network gas emissions, especially with regard to $\mathrm{N}_{2} \mathrm{O}$. Moreover, the fact that none of the articles include all three gases at the same time limits the understanding of how the mechanisms interact and limit each other. Additionally, the reviewed articles mainly focus on rising sewers, and little attention is given to networks combining both, pressurised and gravity sewers.

There is a great degree of variability amongst the results as has been previously pointed out. Most studies represented their results in different ways and considering many assumptions. For example, Clemens and Haas [22] assumed that the emissions of the entire sewer corresponded to the emission of four manholes, whereas other studies focused only on specific emissions at the influent of the WWTP $[21,23,30,37]$. This means that comparison among studies is not straight forward, given that the conditions (aerobic, anaerobic, anoxic) and representativeness of the sewer network are very diverse. Therefore, concluding that one site has more emissions than another can be misleading.

Furthermore, different sampling methods were used in the quantification of the emissions. Most of the studies rely on the dissolved gas concentration in the liquid phase to calculate the concentrations in the gas phase $[12,13,23,24,33,35,36]$. Other authors base their results directly on gas sampling methods $[15,22,31,38]$. However, it is rare to find studies where both liquid and gas sampling methods were combined and, as a result, comparing amongst studies is not straightforward (Table 1). Moreover, measures in the liquid phase are mostly made by stripping the dissolved gas and by using gas chromatography, which does not represent the real emission in a sewer, but the potential emission considering that all dissolved gas is stripped out at certain moment. An additional problem when measuring in the liquid phase is that turbulent areas could significantly underestimate the concentration of the dissolved gases. This is due to the fact that turbulence creates pressure drops which result in release of substances to the gas phase. Considering that sewer basic components like manholes, wells, weirs, connections, slopes and pumps increase the turbulence [50], this parameter should be considered when comparing and presenting the results. Nevertheless none of the studies correlate turbulence measurements with emissions. Moreover, it would be useful to determine whether the same results are obtained when measuring in the gas or in the liquid phase.

Also, the sampling plans used in the studies were very different in terms of duration and frequency of the measurements. In the case of [22], for instance, samples were taken during two days to determine longitudinal changes in $\mathrm{N}_{2} \mathrm{O}$ emissions. In contrast, [23] took monthly samples at the influent of three different WWTPs for eight months in order to detect seasonal variations in the emissions. Daelman et al. [28] concluded that the most accurate option is long-term sampling for $\mathrm{CH}_{4}$ and $\mathrm{N}_{2} \mathrm{O}$ measurements in WWTPs, as it covers different temperatures, days of the week and times of the day. This assertion should be also considered in the analysis of sewers, given that there are greater variations among seasons and times of the day.

In general, correlations between gas emissions and wastewater composition are difficult to establish because authors seldom report other parameters such as $\mathrm{COD}, \mathrm{NH}_{4}{ }^{+}, \mathrm{NO}_{2}{ }^{-}$or $\mathrm{NO}_{3}{ }^{-}, \mathrm{pH}$, temperature, flow rate, HRT, conductivity or redox potential. It was demonstrated that the presence of nitrogen-related compounds such as $\mathrm{NO}_{2}{ }^{-}$or $\mathrm{NO}_{3}{ }^{-}$can reduce the $\mathrm{CH}_{4}$ and $\mathrm{H}_{2} \mathrm{~S}$ 
emissions [30,34-36]. However, [10-12,15,24,31-33,36-38,40] do not report $\mathrm{NO}_{2}^{-}$or $\mathrm{NO}_{3}^{-}$ concentrations in the wastewater. Thus, it is difficult to establish if low concentration of $\mathrm{CH}_{4}$ is due to the presence of nitrates and nitrites in the sewer. Similarly, the addition of DO also reduces the production of $\mathrm{CH}_{4}$ and $\mathrm{H}_{2} \mathrm{~S}$, as they are formed in anaerobic conditions [13,38], yet these are not given in most of the studies [11-13,15,21-24,31-37,40]. Therefore, in order to determine the gas production pathways and the factors that foster their release to the sewer atmosphere, it is important to provide these key parameters. Additionally, the sewer configuration and the geographic location must be considered. Depending on the features of each city, especially the slope and the location of the WWTP, wastewater might have different HRTs [5]. As a result, the gas production rate in different cities varies depending on the sewer design [32,39]. Nevertheless, given the complexity of sewer networks, to the best of our knowledge no studies addressing the entire network have been reported.

With regard to the geographic location, climate plays an important role in the wastewater flows circulating in combined sewers, where waste- and stormwater are collected in the same pipeline. In this case, little data are reported on environmental conditions such as rainfall and other factors that can influence the production of the emissions. Given that water flushing is a technique that reduces $\mathrm{H}_{2} \mathrm{~S}$ formation in sewers [38], lower gas emissions should be expected in areas with heavier precipitation events. Besides rainfall, atmospheric temperature is also relevant. Willis et al. [40] reported that greater $\mathrm{CH}_{4}$ emissions take place in summer than in winter, which points out that seasonality is a parameter to consider. In general, however, the analyses do not specify the season in which the sampling campaigns were conducted and this hinders the comparison amongst the results. Additionally, most studies were developed in Australia and consequently there is no representation of other climatic regions.

Therefore, having identified some of the research gaps in this field, we next present a case study of the gas emissions in the sewer network of two different cities. The main issues we tried to address in this analysis were: the integrated assessment of the three gases, the effect of temperature in different climatic regions and seasons of the year and the inclusion of different constructive components of sewers. In addition, we provide gas concentrations and emission factors, albeit we were limited in correlating these factors to wastewater composition.

\section{Case studies for analyzing $\mathrm{CH}_{4}, \mathrm{H}_{2} \mathrm{~S}$ and $\mathrm{N}_{2} \mathrm{O}$ emissions in sewer networks}

\subsection{Sampling sites and methodology}

In order to determine the $\mathrm{CH}_{4}, \mathrm{H}_{2} \mathrm{~S}$ and $\mathrm{N}_{2} \mathrm{O}$ that could be generated in real sewer networks, two small-to-medium sized Spanish cities representative of the Mediterranean and Atlantic climates were selected. This study was conducted in the framework of the LIFE+ Aquaenvec project (LIFE10/ENV/ES/520), which focuses on the eco-efficiency of the entire urban water cycle. The cities studied were Calafell in Catalonia and Betanzos in Galicia. Supporting information 3 presents some figures of each municipality and the main features of their sewer networks. It must be noted that Calafell is a coastal tourist destination and its population duplicates in summer. Also, the pumping requirements in Calafell are greater than Betanzos, where much of the sewer has a gravity flow. Both cities have combined sewer networks that transport mostly domestic wastewater and some wastewater from nearby industrial parks. However, Betanzos industrial park hosts commercial, distribution and transportation activities, so its wastewater can be considered to be the same as domestic wastewater, and the contribution of the industrial park of Calafell represents less than $1 \%$ of the total flow that carries the sewer system. 
Five sites were selected in the sewer network of each city so that the concentration of each gas produced under different conditions and sewer components was sampled (Table 2). All the wastewater passing through the sampling points was mainly of domestic origin. A map showing the location and altitude of each sampling site is provided in Supporting information 4. Betanzos WWTP was designed for 25,000 population equivalent (p.e.) with a maximum flow of $466 \mathrm{~m}^{3} \mathrm{~h}^{-}$ ${ }^{1}$ while Calafell WWTP was designed for 70,000 p.e. with a maximum flow of $500 \mathrm{~m}^{3} \mathrm{~h}^{-1}$.

The summer sampling campaign was carried out in Betanzos during the first and in Calafell during the second week of July 2013. The winter campaign was performed during the fourth week of January 2014 for Calafell and the second week of February 2014 for Betanzos. It should be stressed that abnormal weather conditions were experienced during both campaigns: Betanzos had a lack of precipitations the week before and during the summer sampling campaign $(0 \mathrm{~mm}$ per day between $24 / 06$ to $06 / 07 / 2013$ ), but, in winter, rainfall was greater than usual (17 mm the night before the campaign) [51]. In Calafell, the precipitations were much more intense than usual, with approximately $9.1 \mathrm{~mm}$ the night previous to the winter sampling campaign (regular values are of less than $1.0 \mathrm{~mm}$ ) and $11.4 \mathrm{~mm}$ the night previous to the summer sampling campaign (regular values less than $0.1 \mathrm{~mm}$ ) [52].

A multi-parametric analyser (Servomex 4900) coupled to a gas conditioner (JCT model JCCP114111) was used for the continuous monitoring of $\mathrm{N}_{2} \mathrm{O}$ and $\mathrm{CH}_{4}$ (Supporting Information 5). In the sewer sampling points, the gas was collected from the headspace using a gas tube connected to the gas conditioner. A closed chamber with an area of $1 \mathrm{~m}^{2}$ was connected to the gas conditioner in the influent of the WWTP. Sampling was conducted continuously (at $100 \mathrm{~L} \mathrm{~h}^{-1}$ ) for at least one hour (data were logged every $10 \mathrm{~s}$ ). Sampling sites were monitored at approximately the same time of the day. In the case of $\mathrm{H}_{2} \mathrm{~S}$, colorimetric tubes were used for the discontinuous sampling of this gas emission. The air flow, pressure and temperature were determined with a TESTO 400 multi-parametric measurer. Wastewater was also sampled in each site, stored at $4^{\circ} \mathrm{C}$ and analysed not more than $24 \mathrm{~h}$ after sampling. Conventional parameters such as the total nitrogen, Total and Soluble Chemical Oxygen Demand (COD and SCOD) and the concentration of $\mathrm{NH}_{4}{ }^{+}, \mathrm{NO}_{2}{ }^{-}$and $\mathrm{NO}_{3}{ }^{-}$were measured at the laboratory using standard procedures (Supporting Information 5). 
Table 2 Description of the sampling sites selected in Betanzos and Calafell. $\mathrm{n} / \mathrm{m}$ : not measured; $\mathrm{n} / \mathrm{a}$ : not available. *Air flow rate expressed as $\mathrm{m}^{3} / \mathrm{h} \cdot \mathrm{m}^{2}$. PS: Pumping station. MH: Manhole

\begin{tabular}{|c|c|c|c|c|c|c|c|c|c|c|}
\hline \multirow{3}{*}{ City } & \multicolumn{2}{|c|}{ Site } & \multirow{2}{*}{\multicolumn{2}{|c|}{ Temperature $\left({ }^{\circ} \mathrm{C}\right)$}} & \multirow{2}{*}{\multicolumn{2}{|c|}{ Pressure (mbar) }} & \multirow{2}{*}{\multicolumn{2}{|c|}{$\begin{array}{l}\text { Air flow rate at the } \\
\text { sampling point }\left(\mathrm{m}^{3} / \mathrm{h}\right)\end{array}$}} & \multirow{3}{*}{$\begin{array}{l}\text { Height above } \\
\text { the sea level } \\
\text { (m) }\end{array}$} & \multirow{3}{*}{ Description } \\
\hline & \multirow{2}{*}{ Name } & \multirow{2}{*}{$\begin{array}{l}\text { Point of } \\
\text { measure }\end{array}$} & & & & & & & & \\
\hline & & & Summer & Winter & Summer & Winter & Summer & Winter & & \\
\hline \multirow{5}{*}{ 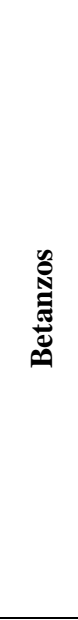 } & $\begin{array}{l}\text { As Cascas } \\
\text { PS }\end{array}$ & Wet well & 23 & 15 & 1018 & 1016 & $\mathrm{n} / \mathrm{a}$ & $\mathrm{n} / \mathrm{a}$ & 27 & $\begin{array}{l}\text { Pumping station receiving wastewater from urban } \\
\text { and rural areas. }\end{array}$ \\
\hline & $\begin{array}{c}\text { As Cascas } \\
\text { discharge } \\
\text { MH } \\
\end{array}$ & Manhole & 23 & 15 & 1018 & 1016 & $\mathrm{n} / \mathrm{a}$ & $\mathrm{n} / \mathrm{a}$ & 12 & The wastewater flow stagnates in the manhole. \\
\hline & $\begin{array}{l}\text { Marina } \\
\text { Street MH }\end{array}$ & Manhole & 23 & 12 & 1018 & 1016 & $\mathrm{n} / \mathrm{a}$ & $\mathrm{n} / \mathrm{a}$ & 26 & $\begin{array}{l}\text { This site collects wastewater from surrounding } \\
\text { buildings }\end{array}$ \\
\hline & $\begin{array}{l}\text { Betanzos } \\
\text { Main PS }\end{array}$ & Wet well & 23 & 14 & 1018 & 1005 & 3.09 & 4.87 & 12 & $\begin{array}{l}\text { Located just before the WWTP. It collects all } \\
\text { wastewater coming from the entire city and pumps } \\
\text { it directly to the WWTP. It has a preliminary rough } \\
\text { screening unit to remove stones and grit. It is } \\
\text { actually considered an important focus of odours. }\end{array}$ \\
\hline & Influent to & ne WWTP & 28 & 14 & 1018 & 1005 & $9.40 *$ & $14.1^{*}$ & 13 & $\begin{array}{l}\text { Wastewater coming from the Betanzos main } \\
\text { pumping station. }\end{array}$ \\
\hline \multirow{5}{*}{ 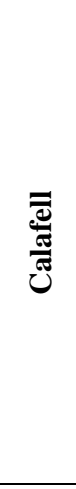 } & Baixador PS & Wet well & 28 & $\mathrm{n} / \mathrm{m}$ & 1012 & $\mathrm{n} / \mathrm{m}$ & 2.57 & $\mathrm{n} / \mathrm{m}$ & 8 & $\begin{array}{l}\text { Pumping station receiving wastewater from the } \\
\text { mid-west region of the city. }\end{array}$ \\
\hline & $\begin{array}{l}\text { Víctor } \\
\text { Català St. } \\
\text { MH }\end{array}$ & Manhole & 28 & 13 & 1012 & 1008 & $\mathrm{n} / \mathrm{a}$ & $\mathrm{n} / \mathrm{a}$ & 3 & $\begin{array}{l}\text { Wastewater flows slowly. It is located few meters } \\
\text { away from Mas Mel PS. }\end{array}$ \\
\hline & Mas Mel PS & Wet well & 31 & 17 & 1014 & 1000 & $\mathrm{n} / \mathrm{a}$ & $\mathrm{n} / \mathrm{a}$ & 3 & $\begin{array}{l}\text { Pumping station receiving wastewater from Víctor } \\
\text { Català and Baixador. }\end{array}$ \\
\hline & $\begin{array}{l}\text { Creu Roja } \\
\text { main PS }\end{array}$ & Wet well & 28 & 14 & 1012 & 1000 & $\mathrm{n} / \mathrm{a}$ & $\mathrm{n} / \mathrm{a}$ & 5 & $\begin{array}{l}\text { Located just before the WWTP. It collects } \\
\text { wastewater coming from the entire city and pumps } \\
\text { it directly to the WWTP. It is actually considered } \\
\text { an important focus of odours. }\end{array}$ \\
\hline & Influent to & ne WWTP & 31 & 14 & 1014 & 998 & $14.1^{*}$ & $13.8^{*}$ & 33 & $\begin{array}{l}\text { Wastewater coming from Creu Roja pumping } \\
\text { station and a commercial centre near the WWTP. }\end{array}$ \\
\hline
\end{tabular}




\subsection{Results and discussion}

The concentrations of $\mathrm{CH}_{4}, \mathrm{H}_{2} \mathrm{~S}$ and $\mathrm{N}_{2} \mathrm{O}$ measured during summer and winter are presented in Figure 2, while Table 3 contains the results of the analyses of the corresponding wastewater. Given that the continuous sampling was conducted during 1 hour, the maximum, minimum and average figures are represented in Supporting Information 6.

Regarding Calafell, $\mathrm{CH}_{4}$ was the gas exhibiting the highest concentration, being one to three orders of magnitude higher than that of $\mathrm{H}_{2} \mathrm{~S}$ and $\mathrm{N}_{2} \mathrm{O}$ (Figure 2A). During summer (average temperature $29.2^{\circ} \mathrm{C}$ ) $\mathrm{CH}_{4}$ concentration ranged between 1.8 to $316.7 \mu \mathrm{g} \mathrm{L}^{-1}(7.2-1267 \mu \mathrm{g}$ COD $\mathrm{L}^{-1}$ ) while in winter (average temperature $14.5^{\circ} \mathrm{C}$ ) the concentration was between 10 to $89.4 \mu \mathrm{g}$ $\mathrm{L}^{-1}$ (40-358 $\mu \mathrm{g}$ COD L L ${ }^{-1}$ ) as shown in Table 3. In previous literature, the reported $\mathrm{CH}_{4}$ concentrations are highly variable (see Section 2.1), but in wet wells and the influent of a WWTP [33] $\left(200 \mu \mathrm{g} \mathrm{L}^{-1}\right)$ and [30] (434-682 $\left.\mu \mathrm{g} \mathrm{L}^{-1}\right)$ present values similar to those in our analysis. As expected, our results indicate that higher temperatures favour the anaerobic $\mathrm{CH}_{4}$ production, but it should be considered that average SCOD was of $191.52 \mathrm{mg} \mathrm{COD} \mathrm{L}^{-1}$ in summer, while in winter these values decrease to $141.40 \mathrm{mg} \mathrm{COD} \mathrm{L}^{-1}$. Hence, this trend implies a reduction in the activity of MB. However, we could not determine from our data to what extent the temperature and/or the availability of SCOD influenced $\mathrm{CH}_{4}$ generation. Furthermore, high concentrations of $\mathrm{CH}_{4}$ do not coincide with high SCOD concentrations in the wastewater. For example, during the summer, Marina St. (manhole) presented high levels of SCOD $\left(537.6 \mathrm{mg} \mathrm{L}^{-1}\right.$ ) that correspond to $20.2 \mu \mathrm{g}$ $\mathrm{L}^{-1}$ of $\mathrm{CH}_{4}$. In contrast, in As Cascas PS (wet well) greater $\mathrm{CH}_{4}$ emissions were measured (1109 $\mu \mathrm{g} \mathrm{L}^{-1}$ ), whereas the SCOD was $179 \mathrm{mg} \mathrm{L}^{-1}$.This leads us to suggest that there are other mechanisms at play that have a stronger influence on methane emissions.

As mentioned in 3.1, other factors affecting $\mathrm{CH}_{4}$ formation (as well as $\mathrm{H}_{2} \mathrm{~S}$ and $\mathrm{N}_{2} \mathrm{O}$ ) are the $\mathrm{pH}$ and the presence of nitrate and nitrite. Due to technical problems the $\mathrm{pH}$ was only measured in the winter with values oscillating between 7.2-7.6, and it was impossible to establish whether the lower concentrations of $\mathrm{CH}_{4}$ in the winter were influenced by the neutral $\mathrm{pH}$ values as described by [30]. Correlations between nitrate/nitrite concentrations and $\mathrm{CH}_{4}$ can be established in some cases from our results. Even though an inhibition concentration threshold of $8 \mathrm{mg} \mathrm{NO}_{3}^{-} \mathrm{L}^{-1}$ and $0.07 \mathrm{mg} \mathrm{NO}_{2}^{-} \mathrm{L}^{-1}$, respectively, has been established by [30], we found that for example Betanzos Main PS (winter campaign) had one of the lowest concentrations of $\mathrm{CH}_{4}\left(15.1 \mu \mathrm{g} \mathrm{L}^{-1}\right)$ with the highest wastewater $\mathrm{NO}_{3}{ }^{-}$concentration of $2.730 \mathrm{mg} \mathrm{L}^{-1}$. In contrast, for the same point in summer campaign, as $\mathrm{NO}_{2}^{-}$and $\mathrm{NO}_{3}^{-}$decrease, methane concentration raises up to $42.4 \mu \mathrm{g} \mathrm{L}^{-1}$. Other sampling points in Calafell such as Baixador PS (wet well) in summer have much lower concentrations of methane $\left(1.8 \mu \mathrm{g} \mathrm{L}^{-1}\right)$, even though there are high levels of nitrates and nitrites (1.130 $\mathrm{mg} \mathrm{NO}_{2}{ }^{-} \mathrm{L}^{-1}$ and $1.423 \mathrm{mg} \mathrm{NO}_{2}{ }^{-} \mathrm{L}^{-1}$ ).

What seems to be true is that high methane emissions occur in wet wells, which have higher turbulence than the other sampling points. Additionally, the wet wells can potentially become anaerobic environments between breathing cycles conducive to the proliferation of MB (see Section 1). For example, the highest concentrations were recorded in Creu Roja PS (316.7 $\mu \mathrm{g} \mathrm{L} \mathrm{L}^{-}$ $\left.{ }^{1}\right)$ and Mas Mel PS $\left(226.9 \mu \mathrm{g} \mathrm{L}^{-1}\right)$. Similarly to $\mathrm{CH}_{4}$, turbulence also affects the release of $\mathrm{N}_{2} \mathrm{O}$ to the atmosphere and higher concentrations of this gas were recorded in wet wells. For instance, in Creu Roja PS 18.3 and $6.8 \mu \mathrm{g} \mathrm{L}^{-1}$ were produced in summer and winter, respectively. However, these values are much lower than the result obtained in manholes by Clemens and Haas ([22], 298 $\left.\mu \mathrm{g} \mathrm{L}^{-1}\right)$. In contrast, no emissions were detected in Marina St. MH. In this case, wastewater has a short HRT because the manhole is located close to the households. 
Given that the average annual rainfall is higher in Betanzos than in Calafell (see Supporting information 3), we could expect less biofilm formation in Betanzos, and therefore lower methane production. However, as was previously mentioned, Betanzos experienced a lack of precipitations the week before the summer sampling campaign, and in winter, rainfall was greater than usual. This fact could have resulted in higher emissions than expected. And in contrast, the precipitations were much more intense than usual in Calafell, both in summer and winter with the corresponding dilution of wastewater (Section 2.1), which on the contrary could decrease these gas concentrations.

As expected, high amounts of $\mathrm{CH}_{4}$ corresponded to lower sulphide concentrations as they compete for the same electron donors. Maximum $\mathrm{H}_{2} \mathrm{~S}$ concentration was $4.3 \mu \mathrm{g} \mathrm{L}^{-1}$, up to 4 orders of magnitude lower than other studies (Table 1). In some cases, this gas could be smelled because it has an odour threshold of $0.0081 \mathrm{ppmv}$, although its concentration was under the detection limit of the equipment $(<0.2 \mathrm{ppmv})$. In winter, no $\mathrm{H}_{2} \mathrm{~S}$ emissions were recorded in Betanzos corresponding to the low sulphate concentration $\left(3.6-18 \mathrm{mg} \mathrm{L}^{-1}\right)$ and high concentrations of SCOD $\left(33.60-548.8 \mathrm{mg} \mathrm{L}^{-1}\right)$ in wastewater. The highest $\mathrm{H}_{2} \mathrm{~S}$ concentrations were detected in the influent of the WWTP in Calafell both in summer and winter. Moreover, the sulphate concentration in Calafell ranges between $63-72 \mathrm{mg} \mathrm{L}^{-1}$, which results in higher emissions than in Betanzos. Given that there is a rising sewer before wastewater enters the WWTP, $\mathrm{H}_{2} \mathrm{~S}$ could be dragged through this stretch and released when there is an opening to the atmosphere.

In order to establish an emission factor, it is necessary to determine the air/water flows at the sampling sites and sewer geometry. Ward et al [53] provide a force balance model for calculating the ventilation of sewers using carbon-monoxide tracer measurements to estimate the air flow inside sewer pipes. Nonetheless, applying this method requires characterizing the drag forces acting at the air-water interface, which is beyond the scope of the present study. Alternatively, the emission factors at the entrance of WWTP were obtained by multiplying the gas concentrations and the air flow at the sampling site. Air velocity was determined by a multi-parametric measurer, which accounted for the gas release from the wastewater surface, considering $1 \mathrm{~m}^{2}$ at the entrance of the WWTP see Section 3.1. Following this method, we obtained higher values of both $\mathrm{CH}_{4}$ and $\mathrm{NO}_{2}$ in summer than in winter. In the case of Calafell, the estimated emissions were $7,447 \mathrm{~kg} \mathrm{CH}_{4}$ year ${ }^{-1}$ and $134 \mathrm{~kg} \mathrm{H}_{2} \mathrm{~S}$ year ${ }^{-1}$ in summer and $1,886 \mathrm{~kg} \mathrm{CH}_{4}$ year $^{-1}$ and $255 \mathrm{~kg} \mathrm{H}_{2} \mathrm{~S}_{\text {year }}{ }^{-1}$ in winter. Regarding Betanzos, these values were 12,087 $\mathrm{kg} \mathrm{CH}_{4}$ year $^{-1}$ and $265 \mathrm{~kg} \mathrm{~N}_{2} \mathrm{O}$ year ${ }^{-1}$ in summer and $4,771 \mathrm{~kg} \mathrm{CH}_{4}$ year $^{-1}$ in winter.

With regard to the environmental impacts, the contribution of these gas emissions to the carbon footprint of sewers was estimated using Life Cycle Assessment (LCA) [54]. This method can be used to calculate the impacts of the life-cycle stages of a product, service or system, from the raw material extraction to the end of life. So far these emissions have not been integrated into the LCA of sewers [55]. In this case, the methodology presented by [56] for the estimation of the impacts of sewers was applied. Following the calculation method presented by [24], we multiplied the summer $\mathrm{CH}_{4}$ and $\mathrm{N}_{2} \mathrm{O}$ emissions, their GWP and the wastewater flows at the influent of the WWTPs (Supporting Information 3). As a result, we obtained an emission factor of 0.32 and $0.61 \mathrm{~kg}$ of $\mathrm{CO}_{2}$ eq. person ${ }^{-1}$ year $^{-1}$ in Calafell and Betanzos, respectively. When integrated into the operation stage of sewers, which includes the electricity consumption to pump wastewater, the direct gas emissions represent between 2 and $16 \%$ of the impacts in Calafell and Betanzos, respectively. When the entire life cycle of waste water treatment is assessed (i.e. raw materials extraction, transport, construction, operation and demolition), the production of $\mathrm{CH}_{4}$ and $\mathrm{N}_{2} \mathrm{O}$ in 
sewers, accounts for 1-3\% of the Global Warming Potential (GWP). Considering that this figure only represents the emissions at the influent, a bigger share of the impacts might be attributed to the total direct GHG emissions of a sewer, as they can be released along the entire network. Hence, they should not be underestimated when assessing the environmental burdens of this type of infrastructure, albeit to the authors' knowledge gas emissions have not been integrated into LCA studies so far.

\section{A-Calafell B-Betanzos}
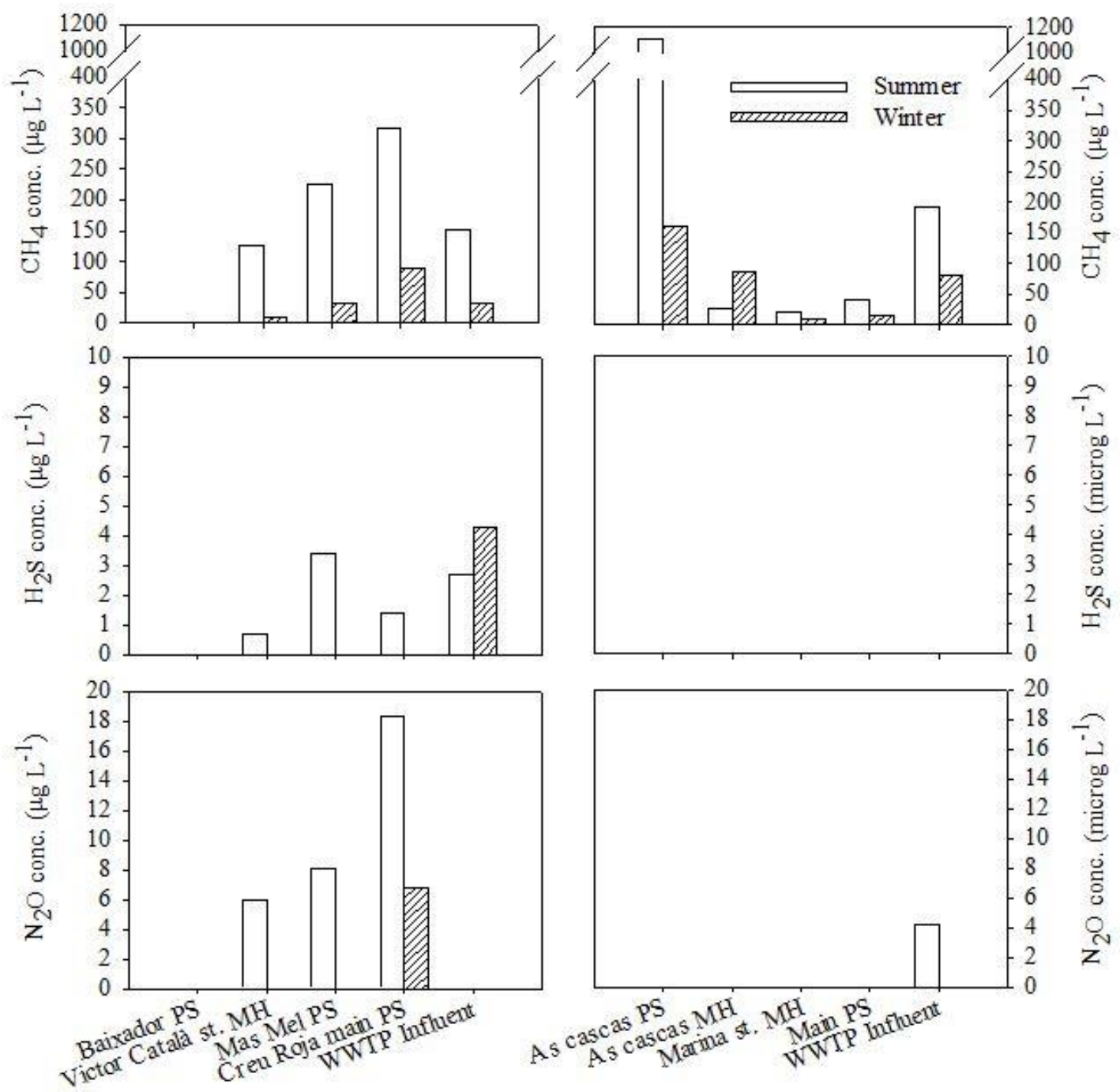

Figure $2 \mathrm{CH}_{4}, \mathrm{H}_{2} \mathrm{~S}$ and $\mathrm{N}_{2} \mathrm{O}$ concentrations measured in the sewer network of Calafell and Betanzos. PS: Pumping station, MH: Manhole. 
Table 3 Results of the wastewater analysis during the sampling campaigns. n/d: not detected; n/m: not measured. PS: Pumping station, MH: Manhole.

\begin{tabular}{|c|c|c|c|c|c|c|c|c|c|c|c|c|c|c|c|c|c|c|c|}
\hline \multirow{3}{*}{$\frac{\text { Sampling Point }}{\text { Parameter/season }}$} & \multicolumn{9}{|c|}{ Calafell } & \multicolumn{10}{|c|}{ Betanzos } \\
\hline & Baixador PS & \multicolumn{2}{|c|}{$\begin{array}{l}\text { Victor Català } \\
\text { St.MH }\end{array}$} & \multicolumn{2}{|c|}{ Mas Mel PS } & \multicolumn{2}{|c|}{ Creu Roja PS } & \multicolumn{2}{|c|}{$\begin{array}{c}\text { Calafell Influent to } \\
\text { the WWTP }\end{array}$} & \multicolumn{2}{|c|}{ As Cascas PS } & \multicolumn{2}{|c|}{ As Cascas MH } & \multicolumn{2}{|c|}{ Marina St. MH } & \multicolumn{2}{|c|}{ Betanzos Main PS } & \multicolumn{2}{|c|}{$\begin{array}{c}\text { Betanzos Influent to } \\
\text { the WWTP }\end{array}$} \\
\hline & Summer Winter & Summer & Winter & Summer & Winter & Summer & Winter & Summer & Winter & Summer & Winter & Summer & Winter & Summer & Winter & Summer & Winter & Summer & Winter \\
\hline $\begin{array}{c}\mathrm{TS} \\
\left(\mathrm{mg} \mathrm{L}^{-1}\right)\end{array}$ & $1587 \mathrm{n} / \mathrm{m}$ & 860.0 & 1407 & 1807 & 2170 & 1793 & 1790 & 1353 & 1936 & 1670 & 1183 & 953.3 & 970.0 & 10893 & 666.7 & 893.3 & 423.3 & 660.0 & 666.7 \\
\hline $\begin{array}{c}\mathrm{VS} \\
\left(\mathrm{mg} \mathrm{L}^{-1}\right)\end{array}$ & $266.7 \quad \mathrm{n} / \mathrm{m}$ & 25.00 & 226.7 & 593.3 & 330.0 & 493.3 & 373.3 & 173.3 & 725.3 & 1050 & 406.7 & 473.3 & 393.3 & 8847 & 310.0 & 353.3 & 76.70 & 300.0 & 320.2 \\
\hline $\begin{array}{c}\text { Total COD } \\
\left(\mathrm{mg} \mathrm{L}^{-1}\right)\end{array}$ & $739.2 \quad \mathrm{n} / \mathrm{m}$ & 324.8 & 336.0 & 1333 & 168.0 & 862.4 & 616.0 & 588.0 & 425.6 & 2856 & 504.0 & 1204 & 1064 & 4032 & 1120 & 537.6 & 134.4 & 616.0 & 436.8 \\
\hline $\begin{array}{c}\text { Soluble COD } \\
\left(\mathrm{mgL}^{-1}\right)\end{array}$ & 330.4 & 162.4 & 145.6 & 168.0 & 72.80 & 162.4 & 173.6 & 134.4 & 173.6 & 179.2 & 39.20 & 263.2 & 548.8 & 537.6 & 352.8 & 212.8 & 33.60 & 224.0 & 78.40 \\
\hline $\mathrm{N}-\mathrm{NH}_{4}{ }^{+}\left(\mathrm{mg} \mathrm{L}^{-1}\right)$ & 32.29 & 46.40 & 27.93 & $\mathrm{n} / \mathrm{d}$ & 23.77 & 31.50 & 36.238 & 37.07 & 40.93 & 37.97 & 6.290 & 69.86 & 35.57 & 7.538 & 67.37 & 34.90 & 7.604 & 30.87 & 11.29 \\
\hline $\mathrm{N}-\mathrm{NO}_{2}^{-}\left(\mathrm{mg} \mathrm{L}^{-1}\right)$ & 1.130 & 0.910 & 0.948 & $\mathrm{n} / \mathrm{d}$ & $\mathrm{n} / \mathrm{d}$ & $\mathrm{n} / \mathrm{d}$ & $\mathrm{n} / \mathrm{d}$ & $\mathrm{n} / \mathrm{d}$ & $\mathrm{n} / \mathrm{d}$ & 0 & 0.080 & 0.723 & 0.272 & 0 & 0 & 0 & 0.208 & $\mathrm{n} / \mathrm{d}$ & 0.577 \\
\hline $\mathrm{N}-\mathrm{NO}_{3}^{-}\left(\mathrm{mg}^{-1} \mathrm{~L}\right)$ & 1.423 & 0.873 & 0.056 & $\mathrm{n} / \mathrm{d}$ & 2.424 & 0.821 & 0.119 & 0.796 & 0.299 & 1.010 & 1.108 & 1.139 & 0.000 & 0 & 0 & 0.922 & 2.730 & $\mathrm{n} / \mathrm{d}$ & 0.844 \\
\hline $\mathrm{S}-\mathrm{SO}_{4}{ }^{2-}\left(\mathrm{mg} \mathrm{L}^{-1}\right)$ & $\mathrm{n} / \mathrm{m}$ & $\mathrm{n} / \mathrm{m}$ & 65.70 & $\mathrm{n} / \mathrm{m}$ & 72.0 & $\mathrm{n} / \mathrm{m}$ & 68.6 & $\mathrm{n} / \mathrm{m}$ & 63.3 & $\mathrm{n} / \mathrm{m}$ & 3.6 & $\mathrm{n} / \mathrm{m}$ & 18.0 & $\mathrm{n} / \mathrm{m}$ & 9.7 & $\mathrm{n} / \mathrm{m}$ & 8.5 & $\mathrm{n} / \mathrm{m}$ & 9.1 \\
\hline $\mathrm{S}-\mathrm{S}_{2} \mathrm{O}_{3}{ }^{2-}\left(\mathrm{mg} \mathrm{L}^{-1}\right)$ & $\mathrm{n} / \mathrm{m}$ & $\mathrm{n} / \mathrm{m}$ & 0.450 & $\mathrm{n} / \mathrm{m}$ & $\mathrm{n} / \mathrm{d}$ & $\mathrm{n} / \mathrm{m}$ & 0.14 & $\mathrm{n} / \mathrm{m}$ & 1.30 & $\mathrm{n} / \mathrm{m}$ & $\mathrm{n} / \mathrm{d}$ & $\mathrm{n} / \mathrm{m}$ & 0.08 & $\mathrm{n} / \mathrm{m}$ & 0.12 & $\mathrm{n} / \mathrm{m}$ & $\mathrm{n} / \mathrm{d}$ & $\mathrm{n} / \mathrm{m}$ & $\mathrm{n} / \mathrm{d}$ \\
\hline $\mathrm{pH}$ & $\mathrm{n} / \mathrm{m}$ & $\mathrm{n} / \mathrm{m}$ & 7.700 & $\mathrm{n} / \mathrm{m}$ & 7.6 & $\mathrm{n} / \mathrm{m}$ & 7.7 & $\mathrm{n} / \mathrm{m}$ & 7.2 & $\mathrm{n} / \mathrm{m}$ & 6.9 & $\mathrm{n} / \mathrm{m}$ & 7.8 & $\mathrm{n} / \mathrm{m}$ & 9.1 & $\mathrm{n} / \mathrm{m}$ & 7.0 & $\mathrm{n} / \mathrm{m}$ & 7.1 \\
\hline
\end{tabular}




\section{Conclusions}

In this paper, the existent literature on the quantification of gas concentrations in sewers is reviewed and research gaps in this field are identified. The main gases analyzed were $\mathrm{CH}_{4}$ and $\mathrm{H}_{2} \mathrm{~S}$, given their toxicity and corrosion potential, whereas there is a lack of in-depth studies on $\mathrm{N}_{2} \mathrm{O}$ emissions in sewer networks. Moreover, none of the studies have simultaneously considered the three gases. In general, the methodological approaches are not uniform. The samples are taken in different phases (liquid/gas), the duration of the campaigns varies from a single wastewater sample to continuous sampling strategies, and the selected sites are not always the same (i.e., manholes, influent, rising main). As a result, the results are not comparable or adequate in establishing an emissions factor applicable to other sewer networks.

In order to address some of the research gaps (the integrated assessment of the three gases, the effect of temperature in different climatic regions and seasons of the year and the inclusion of different constructive elements of sewers), we presented a case study of the gas emissions in the sewer network of two different cities. In the analysis of case studies, results are presented in concentration units, as they were measured in the gas phase. The sampling points were selected to cover different conditions of the network. It was detected that the emissions are especially high in Mediterranean cities when compared to Atlantic cities, where yearly average temperature and turbulence seem to play an important role in the release of gaseous compounds. Moreover, higher concentrations were detected in summer than in winter, which also confirms that temperature is an important factor. In the case of methane, values up to $316.7 \mu \mathrm{g} \mathrm{L}^{-1}$ were recorded, with the same order than [33] measured $\left(200 \mu \mathrm{g} \mathrm{L}^{-1}\right)$. Nitrous oxide concentrations were higher in wet wells, up to $18.3 \mu \mathrm{g} \mathrm{L}^{-1}$, where turbulence is higher than in other points, but much lower than the value reported by [22] $\left(298 \mu \mathrm{g} \mathrm{L}^{-1}\right)$. Hydrogen sulphide concentrations were low $\left(4.3 \mu \mathrm{g} \mathrm{L}^{-1}\right.$ as a maximum), as expected because of the high amounts of methane detected and a few orders of magnitude lower than those reported by [35] (5000-7000 $\left.\mu \mathrm{g} \mathrm{L}^{-1}\right)$. However, [31] presented values even lower than ours (from 0.04 to $0.76 \mu \mathrm{g} \mathrm{L}^{-1}$ ).

The two-season sampling scheme evidenced some limitations of the study and how it can be improved in the future. Firstly, the continuous sampling was carried out for an hour, and it was too short and not representative of fluctuations in wastewater generation during the day. Secondly, measurements in wet wells should cover their entire breathing cycle to determine variations in DO concentrations. In addition, other parameters such as the redox potential and water temperature should be included in order to account for the environmental conditions. This way, cause-effect relationships between the gas formation and the water species detected can be addressed. Finally, the sewer network should be thoroughly characterised so as to select consecutive sampling sites with known additional wastewater contributions. Given that correlations between parameters could not be easily reported, future analyses should include a detailed characterisation of the sewer network and the environmental conditions of the sampling sites. Hence, more knowledge about the mechanisms, conditions and geometrical and operational features of sewers that give rise to emissions is needed to calculate the emission factors. Moreover, manual and online monitoring of some part of the sewer system is not sufficient to account for the emissions of the entire network. Therefore, modelling is necessary on a systemwide basis, and sampling in real sewers assists in the validation of the models.

In addition, this study showed that the environmental impacts deriving from the direct gas emissions are not irrelevant when compared to other life-cycle impacts of sewers, even if only 
one sampling site was included. Further characterization of the GWP of the sewer network is important in order to inform urban planners and water services how to manage this infrastructure appropriately and to minimize its environmental impact contribution to the urban water life cycle.

\section{Acknowledgements}

The authors wish to thank the LIFE funding programme from the European Commission in the framework of the Aquaenvec project (LIFE10/ENV/ES/520) "Assessment and improvement of the urban water cycle eco-efficiency using LCA and LCC". They also wish to express appreciation for the grants awarded to A. Petit-Boix by Generalitat de Catalunya (FI-DGR 2014) and the Spanish Ministry of Education (FPU13/01273), and E. Eijo-Río by Universitat Autònoma de Barcelona. The authors also acknowledge the collaboration of Concello de Betanzos, Viaqua, Ajuntament de Calafell and SOREA in data gathering in Betanzos and Calafell municipalities and the USC for the analytical measurements of the wastewater samples. 


\section{References}

[1] UN. United Nations. Department of Economic and Social Affairs. Population Division, World Urbanization Prospects: The 2011 Revision, CD-ROM Edition., 2012.

[2] A. Listowski, H.H. Ngo, W.S. Guo, S. Vigneswaran, H.S. Shin, H. Moon, Greenhouse Gas (GHG) Emissions from Urban Wastewater System : Future Assessment Framework and Methodology, J. Water Sustain. 1 (2011) 113-125.

[3] M.R.J. Doorn, S. Towprayoon, S.M. Manso Vieira, W. Irving, C. Palmer, R. Pipatti, et al., 2006 IPCC Guidelines for National Greenhouse Gas Inventories, Chapter 6: Wastewater Treatment and Discharge, Japan, 2006.

[4] European Commission. Joint Research Centre (JRC)/ Netherlands Environmental Assessment Agency (PBL), Emission Database for Global Atmospheric Research (EDGAR), release version 4.0., (2009). http://edgar.jrc.ec.europa.eu.

[5] D. Butler, J.W. Davies, Urban Drainage, 3rd Ed, Spon Press, an imprint of Taylor \& Francis. London and New York., 2000.

[6] F. Jiang, D.H.-W. Leung, S. Li, G.-H. Chen, S. Okabe, M.C.M. van Loosdrecht, A biofilm model for prediction of pollutant transformation in sewers., Water Res. 43 (2009) 3187-98. doi:10.1016/j.watres.2009.04.043.

[7] A. Boon, Septicity in sewers - Causes, consequences and containment, Water Sci. Technol. 31 (1995) 237-253.

[8] A. Boon, A. Vincent, K. Boon, Avoiding the problems of septic sewage, Water Sci. Technol. 37 (1998) 223-231.

[9] USEPA, Process Design Manual for Sulfide Control in Sanitary Sewerage Systems, 1974.

[10] C. Yongsiri, S.M. Asce, J. Vollertsen, T. Hvitved-jacobsen, Influence of Wastewater Constituents on Hydrogen Sulfide Emission in Sewer Networks, J. Environ. Eng. 131 (2005) 1676-1683.

[11] O. Lahav, A. Sagiv, E. Friedler, A different approach for predicting H2S(g) emission rates in gravity sewers., Water Res. 40 (2006) 259-66. doi:10.1016/j.watres.2005.10.026.

[12] A. Guisasola, D. de Haas, J. Keller, Z. Yuan, Methane formation in sewer systems., Water Res. 42 (2008) 1421-30. doi:10.1016/j.watres.2007.10.014.

[13] K.R. Sharma, Z. Yuan, D. de Haas, G. Hamilton, S. Corrie, J. Keller, Dynamics and dynamic modelling of H2S production in sewer systems., Water Res. 42 (2008) 252738. doi:10.1016/j.watres.2008.02.013.

[14] J. Vollertsen, A.H. Nielsen, H.S. Jensen, T. Wium-Andersen, T. Hvitved-Jacobsen, Corrosion of concrete sewers--the kinetics of hydrogen sulfide oxidation., Sci. Total Environ. 394 (2008) 162-70. doi:10.1016/j.scitotenv.2008.01.028. 
[15] D. Chen, P. Szostak, Factor analysis of H2S emission at a wastewater lift station: a case study., Environ. Monit. Assess. 185 (2013) 3551-60. doi:10.1007/s10661-012-2809-4.

[16] S. Solomon, D. Qin, M. Manning, Z. Chen, M. Marquis, K.B. Averyt, et al., Contribution of Working Group I to the Fourth Assessment Report of the Intergovernmental Panel on Climate Change, 2007, Cambridge University Press, Cambridge, United Kingdom and New York, NY, USA., 2007.

[17] H.M. Guinée JB, Gorrée M, Heijungs R, Huppes G, Kleijn R, Koning A de, Oers L van, Wegener Sleeswijk A, Suh S, Udo de Haes HA, Bruijn H de, Duin R van, Handbook on life cycle assessment. Operational guide to the ISO standards. I: LCA in perspective. IIa: Guide. IIb: Operational annex. III: Scientific background, Kluwer Academic Publishers, ISBN 1-4020-0228-9, Dordrecht, 692 pp., 2002.

[18] J.L. Davis, N. Dana, S. Kameron, D.. J. Roberts, Analysis of concrete from corroded sewer pipe, Int. Biodeterior. Biodegradation. 42 (1998) 75-84. doi:10.1016/S09648305(98)00049-3.

[19] A.H. Nielsen, J. Vollertsen, H.S. Jensen, T. Wium-Andersen, T. Hvitved-Jacobsen, Influence of pipe material and surfaces on sulfide related odor and corrosion in sewers, Water Res. 42 (2008) 4206-4214.

[20] USEPA. United States Environmental Protection Agency, Overview of Greenhouse Gases, (2013). http://epa.gov/climatechange/ghgemissions/gases.html Accessed September 2013.

[21] W. Debruyn, G. Lissens, J. Rensbergen, M. Wevers, Nitrous oxide emissions from waste water, 31 (1994) 159-165.

[22] J. Clemens, B. Haas, Nitrous Oxide Emissions in Sewer Systems, Acta Hydrochim. Hydrobiol. 25 (1997) 96-99. doi:10.1002/aheh.19970250207.

[23] M.D. Short, A. Daikeler, G.M. Peters, K. Mann, N.J. Ashbolt, R.M. Stuetz, et al., Municipal gravity sewers: An unrecognised source of nitrous oxide., Sci. Total Environ. 468-469 (2014) 211-8. doi:10.1016/j.scitotenv.2013.08.051.

[24] P. Foley, J., Lant, Direct Methane and Nitrous Oxide emissions from full-scale wastewater treatment systems, Water Serv. Assoc. Aust. Ltd. (2009).

[25] M.J. Kampschreur, H. Temmink, R. Kleerebezem, M.S.M. Jetten, M.C.M. van Loosdrecht, Nitrous oxide emission during wastewater treatment., Water Res. 43 (2009) 4093-103. doi:10.1016/j.watres.2009.03.001.

[26] J. Desloover, S.E. Vlaeminck, P. Clauwaert, W. Verstraete, N. Boon, Strategies to mitigate $\mathrm{N} 2 \mathrm{O}$ emissions from biological nitrogen removal systems., Curr. Opin. Biotechnol. 23 (2012) 474-82. doi:10.1016/j.copbio.2011.12.030.

[27] A.D. Lotito, P. Wunderlin, A. Joss, M. Kipf, H. Siegrist, Nitrous oxide emissions from the oxidation tank of a pilot activated sludge plant, Water Res. 46 (2012) 3563-3573.

[28] M.R.J. Daelman, B. De Baets, M.C.M. van Loosdrecht, E.I.P. Volcke, Influence of sampling strategies on the estimated nitrous oxide emission from wastewater treatment plants., Water Res. 47 (2013) 3120-30. doi:10.1016/j.watres.2013.03.016. 
[29] Metcalf and Eddy. Inc, Wastewater Engineering: Treatment, Disposal and Reuse, 3rd ed, McGraw-Hill, New York, 1991.

[30] J. Wang, J. Zhang, H. Xie, P. Qi, Y. Ren, Z. Hu, Methane emissions from a full-scale A/A/O wastewater treatment plant., Bioresour. Technol. 102 (2011) 5479-85. doi:10.1016/j.biortech.2010.10.090.

[31] F. Dincer, A. Muezzinoglu, Odor Determination at Wastewater Collection Systems: Olfactometry versus H2S Analyses, CLEAN - Soil, Air, Water. 35 (2007) 565-570. doi:10.1002/clen.200700057.

[32] A. Guisasola, K.R. Sharma, J. Keller, Z. Yuan, Development of a model for assessing methane formation in rising main sewers., Water Res. 43 (2009) 2874-84. doi:10.1016/j.watres.2009.03.040.

[33] O. Gutierrez, G. Sudarjanto, G. Ren, R. Ganigué, G. Jiang, Z. Yuan, Assessment of pH shock as a method for controlling sulfide and methane formation in pressure main sewer systems., Water Res. 48 (2014) 569-78. doi:10.1016/j.watres.2013.10.021.

[34] G. Jiang, K.R. Sharma, A. Guisasola, J. Keller, Z. Yuan, Sulfur transformation in rising main sewers receiving nitrate dosage, Water Res. 43 (2009) 4430-4440. doi:10.1016/j.watres.2009.07.001.

[35] G. Jiang, O. Gutierrez, K.R. Sharma, Z. Yuan, Effects of nitrite concentration and exposure time on sulfide and methane production in sewer systems., Water Res. 44 (2010) 4241-51. doi:10.1016/j.watres.2010.05.030.

[36] J. Mohanakrishnan, O. Gutierrez, R.L. Meyer, Z. Yuan, Nitrite effectively inhibits sulfide and methane production in a laboratory scale sewer reactor., Water Res. 42 (2008) 3961-71. doi:10.1016/j.watres.2008.07.001.

[37] A.H. Nielsen, P. Lens, J. Vollertsen, T. Hvitved-Jacobsen, Sulfide-iron interactions in domestic wastewater from a gravity sewer., Water Res. 39 (2005) 2747-55. doi:10.1016/j.watres.2005.04.048.

[38] F. Othman, S. Mortezania, Efficiency assessment of operational and maintenance techniques to optimize sewer gas amount, Int. J. Phys. Sci. 5 (2010) 1381-1388.

[39] J. Porro, L. Guo, K. Sharma, L. Benedetti, S. Van Hulle, P.A. Vanrolleghem, et al., Towards a benchmarking tool for minimizing wastewater utility greenhouse gas footprints., in: Watermatex 2011 Conf. Proceedings, 8th IWA Symp. Syst. Anal. Integr. Assessment, San Sebastian, Spain., 2011: pp. 2483-95. doi:10.2166/wst.2012.495.

[40] J. Willis, R. Barnes, L. Fillmore, A. Shah, Quantifying Methane Evolution from Sewers : Phase 1 Results of the, in: Proc. Water Environ. Fed. WEFTEC 2010, Oct. 2-6, New Orleans, LA, 2010: pp. 5411-09.

[41] P.H. Nielsen, K. Raunkjaer, T. Hvitved-Jacobsen, Transformation of wastewater in sewer system - a review, Water Sci. Technol. 25 (1992) 17-31.

[42] J. Hvitved-Jacobsen, T. Vollertsen, N. Tanaka, An integrated aerobic/anaerobic approach for prediction of sulphide formation in sewer, Water Sci. Technol. 41 (2000) 107-115. 
[43] L. Zhang, P. De Schryver, B. De Gusseme, W. De Muynck, N. Boon, W. Verstraete, Chemical and biological technologies for hydrogen sulfide emission control in sewer systems: a review., Water Res. 42 (2008) 1-12. doi:10.1016/j.watres.2007.07.013.

[44] O. Gutierrez, D. Park, K.R. Sharma, Z. Yuan, Effects of long-term pH elevation on the sulfate-reducing and methanogenic activities of anaerobic sewer biofilms., Water Res. 43 (2009) 2549-57. doi:10.1016/j.watres.2009.03.008.

[45] USEPA. United States Environmental Protection Agency, Handbook: Sewer System Infrastructure Analysis and Rehabilitation, Office of Research and Development. Cincinnati OH 45268., 1991.

[46] Y.-H. Ahn, Sustainable nitrogen elimination biotechnologies: A review, Process Biochem. 41 (2006) 1709-1721. doi:10.1016/j.procbio.2006.03.033.

[47] K.Y. Park, Y. Inamori, M. Mizuochi, K.H. Ahn, Emission and control of nitrous oxide from a biological wastewater treatment system with intermittent aeration., J. Biosci. Bioeng. 90 (2000) 247-52. http://www.ncbi.nlm.nih.gov/pubmed/16232852.

[48] T. Osada, K. Kuroda, M. Yonaga, Reducing nitrous oxide gas emissions from fill-anddraw type activated sludge process, Water Res. 29 (1995) 1607-1608.

[49] P. Czepiel, P. Crill, R. Harriss, Nitrous oxide emissions from municipal wastewater treatment., Environ. Sci. Technol. 29 (1995) 2352-6. doi:10.1021/es00009a030.

[50] T. Hvitved-Jacobsen, J. Vollertsen, A.H. Nielsen, Sewer Processes: Microbial and Chemical Process Engineering of Sewer Networks, 2nd ed, CRC Press, 2002.

[51] Meteogalicia, Estacións meteorolóxicas, (2014).

http://www2.meteogalicia.es/galego/observacion/estacions/estacionsHistorico.asp?Nest= $19045 \&$ prov=Pontevedra\&red=102109\&tiporede=agro\&idprov=3\# (accessed July 1 , 2014).

[52] Meteocat. Servei Meteorològic de Catalunya, Automatic stations (Estacions automàtiques), (2014). http://www.meteo.cat/xema/AppJava/Mapper.do Accessed April 2014.

[53] M. Ward, R. Corsi, R. Morton, T. Knapp, D. Apgar, C. Quigley, et al., Characterization of natural ventilation in wastewater collection systems, Water Environ. Res. 83 (2011) 265-273.

[54] ISO. International Organization for Standardization, Environmental management - life cycle assessment — principles and framework. International Standard 14040, Geneva, 2006.

[55] P. Loubet, P. Roux, E. Loiseau, V. Bellon-Maurel, Life cycle assessments of urban water systems: A comparative analysis of selected peer-reviewed literature, Water Res. 67 (2014) 187-202. doi:10.1016/j.watres.2014.08.048.

[56] Petit-Boix A, Sanjuan-Delmás D, Gasol CM, Villalba G, Suárez-Ojeda ME, Gabarrell X, Josa A, J. Rieradevall, Environmental Assessment of Sewer Construction in Small to Medium Sized Cities Using Life Cycle Assessment, Water Resour. Manag. 28 (2014) 979-997. doi:10.1007/s11269-014-0528-z. 